\title{
Применение ионообменной хроматографии для очистки гликолатоксидазы из листьев гороха (Pisum sativum L.) и сорго (Sorghum sudanense J.), исследование ее физико-химических и регуляторных свойств
}

\author{
Комарова Н.Р., Фалалеева М.И., Ковалёва Е.В., \\ Миткевич А.В., Епринцев А.Т. \\ ФГБОУ ВО «Воронежский государственный университет», Воронеж
}

Поступила в редакцию 30.10.2018 г.

DOI: https://doi.org/10.17308/sorpchrom.2019.19/650

В листьях гороха (Pisum sativum L.) и сорго (Sorghum sudanense J.) индуцировалась активность одной из изоформ гликолатоксидазы (ЛЦО-подобная ГО, КФ 1.1.3.15). С помощью многостадийной очистки, включающей фракционирование сульфатом аммония, ионобменную хроматографию на ДЭАЭ-сефацеле и гель-хроматографию на сефадексе G-200 фермент был очищен до электрофоретически гомогенного состояния. Препарат ЛЦО-подобной ГО из листьев гороха обладал удельной активностью 314.37 Е/мг белка, при этом степень очистки составила 207 раз, а выход - 11.5\%. Аналогичные показатели фермента из листьев сорго составили: 274.22 Е/мг белка, степень очистки - 143 раз, а выход - 13.8\%. Изучены физико-химические свойства фермента из этих объектов. Определена величина молекулярной массы нативной молекулы (182 кДа и 168 кДа для гороха и сорго соответственно), показано, что фермент состоит из четырех субъединиц, молекулярная масса которых определенная ПААГ-электрофорезом в присутствии ДДС-Nа равняется 45 кДа для ГО из листьев гороха и 42 кДа - из сорго. Исследованы кинетические и регуляторные свойства: значения констант Михаэлиса, влияние концентрации ионов водорода и температуры на катализируемую реакцию.

Ключевые слова: гель-хроматография, гликолатоксидаза, ионообменная хроматография, электрофорез, кинетика

\section{Application of ion-exchange chromatography for the purification of glycolatoxidase from the leaves of the pea (Pisum sativum L.) and sorgo (Sorghum sudanense J.), investigation of its physical and chemical and regulatory properties}

\author{
Komarova N.R., Falaleeva M.I., Kovaleva E.V., \\ Mitkevich A.V., Eprintsev A.T. \\ Voronezh State University, Voronezh
}

The enzyme glycolate oxidase (EC 1.1.3.15) is widely distributed and studied, mainly in mammals and plants. In green plants, glycolate oxidase is one of the key enzymes in photorespiration, where it oxidizes glycolate to glyoxylate. It was found that, in addition to glycolate, this enzyme can use lactate as a substrate. In our work, we assumed that GO, being constitutive for plants, functions in both pea leaves and sorghum. In 
pea leaves (Pisum sativum L.) and sorghum (Sorghum sudanense J.), the activity of one of the glycolate oxidase isoforms (l-Lactate Cytochrome c Oxidoreductase-like glycolate oxidase, EC 1.1.3.15) was induced. Using multi-stage purification, including ammonium sulfate fractionation, ion exchange chromatography on DEAE-Sephacel and gel chromatography on sephadex G-200, the enzyme was purified to an electrophoretic homogeneous state. The preparation LCO-like GO from pea leaves had a specific activity of $314.37 \mathrm{U} / \mathrm{mg}$ protein, while the degree of purification was 207 times, and the yield was $11.5 \%$. Similar indicators of the enzyme from sorghum leaves were: $274.22 \mathrm{U} / \mathrm{mg}$ protein, purification degree - 143 times, and yield $13.8 \%$. The physicochemical properties of the enzyme from these objects were studied. The molecular weight of the native molecule was determined (182 kDa and $168 \mathrm{kDa}$ for peas and sorghum, respectively); it was shown that the enzyme consists of four subunits, the molecular weight of which is determined by PAGelectrophoresis in the presence of DDS-Na is $45 \mathrm{kDa}$ for GO from pea leaves and $42 \mathrm{kDa}$ - from sorghum. The kinetic and regulatory properties were investigated: the values of the Michaelis constants, the effect of the concentration of hydrogen ions and the temperature on the catalyzed reaction.

Keywords: gel chromatography, glycolate oxidase, ion exchange chromatography, electrophoresis, kinetics

\section{Введение}

Фермент гликолатоксидаза (КФ 1.1.3.15) широко распространен и изучен, главным образом, у млекопитающих и растений. В зеленых растениях гликолатоксидаза является одним из ключевых ферментов в фотодыхании, где он окисляет гликолат до глиоксилата [1]. Было установлено, что помимо гликолата даннный фермент может использовать и лактат в качестве субстрата [2]. Также, при сопоставлении последовательностей аминокислот и нуклеотидных последовательностей, было выявлено высокое сходство гликолатоксидазы арабидопсиса и шпината с ферментом Lлактат-цитохром-с-оксидоредуктазой дрожжей (КФ 1.1.2.3), который утилизирует лактат в анаэробных условиях [3]. На основании литературных данных был сделан вывод, что фермент аналогичный ферменту ЛЦО дрожжей, присутствует в растениях и представляет собой изоформу гликолатоксидазы (КФ 1.1.3.15). Предполагается, что данная изоформа обладает более высоким сродством к лактату, по сравнению со стандартным субстратом ГО - гликолатом. Ранее Engqvist M.K.M. et all предположили, что данный фермент выполняет адаптивную роль при переходе растений от гипоксии к нормоксии функционируя в корнях [3]. В нашей работе, мы предположили, что фермент ГО, являясь конститутивным для растений [4], функционирует и в листьях гороха, и сорго. В связи с этим была поставлена цель выделить и очистить до гомогенного состояния препараты фермента гликолатоксидазы из листьев сорго и гороха, и изучить их физико-химические и регуляторные свойства. Эти растения, осуществляющие С3 и С4 типы фотосинтеза, представляют интерес в изучении ряда свойств на менее и более устойчивых к стрессовым воздействиям видах.

\section{Эксперимент}

Растительный материал. В качестве объекта исследований использовали листья гороха (Pisum sativum L., сорт Амброзия) и сорго (Sorghum sudanense J., сорт Воронежская). Пластиковые контейнеры, заполненные древесными опилками, с проросшими растениями инкубировали 42 суток в камере для роста растений LabTech в контролируемых условиях: $12 / 12$ ч свет/темнота, при температуре $25^{\circ} \mathrm{C}$. За 24 часа до исследования растения были помещены в темноту, для снижения активности других изоформ гликолатоксидазы, непосредственно участвующих в фотодыхании [5].

Очистка ЛЦО-подобной гликолатоксидазы из листьев гороха и сорго. Очистка ферментов включала их экстракцию из гомогенизированных листьев растений, гель-фильтрацию на колонке $(1.5 \times 20$ см) с Сефадексом G-25, ионообменную хрома- 
тографию DEAE Sephacel («GE Healthcare», Швеция), гель-хроматографию на колонке $(2.0 \times 40$ см) с сефадексом G-200 («GE Healthcare», Швеция) [6]. Сухие сефадексы предварительно замачивали в буферных растворах согласно методике, указанной в работе Селеменева В.Ф. с соавт. [7].

Измерение активности ЛЦО-подобной ГО. Для измерения активности ЛЦОподобной ГО реакционная среда содержала $2 \mathrm{~cm}^{3} 50$ мM Tris-HCl- буфера, (pH 7.5), 4 мМ лактат натрия/гликолат натрия, 0.5 мМ ЭДТА, $0.01 \mathrm{MM} Ф \mathrm{MH}, 5 \mathrm{mM} \mathrm{MgCl}_{2}$ и 4 мМ фенилгидразин. Активность каждой фракции измеряли с обоими субстратами, для исследования отбирали пробы, проявляющие более высокую активность с лактаTом.

Молекулярную массу белка определяли методом гель-фильтрации на колонке сефадекс G-200, для калибровки которой был использован Dextran blue (2000 кДа). Для расчета использовали формулу

$$
\lg M_{r}=6.698-0.987\left(\frac{V_{e}}{V_{o}}\right),
$$

где $\mathrm{V}_{\mathrm{e}}$ - объем элюции белка и $\mathrm{V}_{\mathrm{o}}$ - свободный объем.

Молекулярную массу субъединиц - методом электрофореза в $12 \%$ ПААГ в присутствии Ds-Na. B качестве белков-маркеров молекулярной массы использовали набор стандартных белков (кДа): 1-b-галактозидаза (116.0); 2-БСА (66.2); 3овальбумин (45.0); 4-ЛДГ (35.0); 5-REase Bsp198 (25.0); 6-b-лактоглобулин (18.4); 7лизоцим (14.4). Гели окрашивали по методике с нитратом серебра [8].

Электрофорез ЛЦО-подобной ГО проводили также в 8\%-ном ПААГ по методу Девиса [9]. Для окрашивания гелей применяли нитрат серебра [8], для специфического определения фермента - тетразолиевый метод [10]. Определение белка проводили по методу Лоури.

Для определения достоверности результатов исследований применяли метод вариационной статистики. Полученные данные обрабатывали с использованием стандартных статистических методов с помощью критерия Стьюдента. Обсуждаются статистически достоверные различия при $\mathrm{p} \leq 0,05$ [11]. Для построения графиков использовали данные, обработанные с помощью программ линейной и параболической аппроксимации.

\section{Обсуждение результатов}

Для выполнения цели исследования представляло интерес выделение фермента в период его максимальной активности. Поэтому для получения ЛЦОподобной ГО в высокоочищенном состоянии использовали листья «взрослых» растений гороха и сорго [3]. Результаты типичной очистки ЛЦО-подобной ГО из листьев гороха и сорго приведены в таблицах 1 и 2 соответственно.

Таблица 1. Очистка ЛЦО-подобной ГО из листьев гороха Pisum sativum L. n=3, p $\leq 0.05$

\begin{tabular}{|c|c|c|c|c|c|c|}
\hline $\begin{array}{c}\text { Стадии очист- } \\
\text { ки }\end{array}$ & $\begin{array}{c}\text { Общий } \\
\text { объем, см }\end{array}$ & $\begin{array}{c}\text { Общая актив- } \\
\text { ность, Е }\end{array}$ & $\begin{array}{c}\text { Белок, } \\
\text { мг }\end{array}$ & $\begin{array}{c}\text { Удельная } \\
\text { активость, } \\
\text { Е/мг }\end{array}$ & $\begin{array}{c}\text { Степень } \\
\text { очистки }\end{array}$ & $\begin{array}{c}\text { Выход, } \\
\%\end{array}$ \\
\hline 1 & 2 & 3 & 4 & 5 & 6 & 7 \\
\hline Супернатант & 18.0 & $137.32 \pm 4.12$ & $\begin{array}{c}90.72 \pm \\
2.72\end{array}$ & $1.51 \pm 0.05$ & 1.0 & 100 \\
\hline $\begin{array}{c}\text { Осаждение } \\
\text { сульфатом } \\
\text { аммония } \\
(30-65 \%)\end{array}$ & 3.4 & $111.73 \pm 3.35$ & $\begin{array}{c}10.47 \pm \\
0.31\end{array}$ & $10.67 \pm 0.32$ & 7.05 & 81.37 \\
\hline
\end{tabular}

Комарова и др. / Сорбционные и хроматографические процессы. 2019. Т. 19. № 1 


\begin{tabular}{|c|c|c|c|c|c|c|}
\hline 1 & 2 & 3 & 4 & 5 & 6 & 7 \\
\hline $\begin{array}{c}\text { Гель- } \\
\text { фильтрация } \\
\text { через сефа- } \\
\text { декс } \\
\text { G-25 }\end{array}$ & 1.7 & $57.86 \pm 1.80$ & $\begin{array}{c}3.29 \pm \\
0.03\end{array}$ & $17.57 \pm 1.67$ & 11.63 & 42.23 \\
\hline $\begin{array}{c}\text { Ионо- } \\
\text { обменная } \\
\text { хрома- } \\
\text { тография на } \\
\text { ДЭАЭ- сефа- } \\
\text { целе } \\
\end{array}$ & 1.2 & $32.39 \pm 0.97$ & $\begin{array}{c}0.62 \pm \\
0.01\end{array}$ & $51.81 \pm 3.78$ & 34.32 & 23.59 \\
\hline $\begin{array}{c}\text { Гель- } \\
\text { хроматогра- } \\
\text { фия на сефа- } \\
\text { дексе } \\
\text { G-200 }\end{array}$ & 0.9 & $15.84 \pm 0.48$ & $\begin{array}{c}0.11 \pm \\
0.02\end{array}$ & $143.59 \pm 4.43$ & 95.09 & 11.53 \\
\hline
\end{tabular}

Таблица 2. Очистка ЛЦО-подобной ГО из листьев сорго Sorghum sudanense J. n=3, p $\leq 0.05$

\begin{tabular}{|c|c|c|c|c|c|c|}
\hline $\begin{array}{l}\text { Стадии } \\
\text { очистки }\end{array}$ & $\begin{array}{c}\text { Общий } \\
\text { объем, } \\
\text { см }^{3}\end{array}$ & $\begin{array}{c}\text { Общая актив- } \\
\text { ность, E }\end{array}$ & $\begin{array}{l}\text { Белок, } \\
\text { мг }\end{array}$ & $\begin{array}{c}\text { Удельная ак- } \\
\text { тивность, } \\
\text { Е/мг } \\
\end{array}$ & $\begin{array}{l}\text { Степень } \\
\text { очистки }\end{array}$ & $\begin{array}{c}\text { Вы- } \\
\text { ход, } \\
\%\end{array}$ \\
\hline Супернатант & 25.0 & $278.74 \pm 8.36$ & $\begin{array}{c}146.25 \pm \\
4.38\end{array}$ & $1.91 \pm 0.06$ & 1.0 & 100 \\
\hline $\begin{array}{c}\text { Осаждение } \\
\text { сульфатом ам- } \\
\text { мония (35\%- } \\
65 \%)\end{array}$ & 4.0 & $204.17 \pm 6.91$ & $\begin{array}{c}20.02 \pm \\
0.60\end{array}$ & $10.20 \pm 0.31$ & 5.35 & 73.24 \\
\hline $\begin{array}{c}\text { Гель- } \\
\text { фильтрация } \\
\text { через сефадекс } \\
\mathrm{G}-25\end{array}$ & 2.3 & $175.00 \pm 4.77$ & $\begin{array}{c}5.72 \pm \\
0.17\end{array}$ & $30.59 \pm 0.92$ & 16.05 & 62.78 \\
\hline $\begin{array}{c}\text { Ионообмен- } \\
\text { ная хрома- } \\
\text { тография на } \\
\text { ДЭАЭ- сефа- } \\
\text { целе }\end{array}$ & 1.5 & $135.00 \pm 1.34$ & $\begin{array}{c}2.54 \pm \\
0.02\end{array}$ & $53.24 \pm 4.36$ & 27.87 & 48.57 \\
\hline $\begin{array}{c}\text { Гельхромато- } \\
\text { графия на се- } \\
\text { фадексе } \\
\text { G-200 }\end{array}$ & 1.0 & $38.50 \pm 1.15$ & $\begin{array}{c}0.14 \pm \\
0.01\end{array}$ & $274.22 \pm 8.23$ & 143.88 & 13.81 \\
\hline
\end{tabular}

В ходе многостадийной очистки были получены электрофоретически гомогенные препараты фермента ЛЦО-подобной ГО из листьев сорго и гороха. Значения удельной активности составили 274.22 Е/мг для сорго и 314.37 Е/мг для гороха, выход 13.81 и $11.54 \%$ соответственно. Известно значительное количество методов, позволяющих эффективно очищать вещества разной природы [12-16]. Важный вклад в получение гомогенного препарата ЛЦО-подобной гликолатоксидазы был внесен использованием ионообменной хроматографии на ДЭАЭ-Сефацеле. Наибольшее количество гликолатоксидазной активности с лактатом было десорбировано с носителя при элюции 150-200 мМ NaCl.

С помощью универсального окрашивания нитратом серебра были выявлены в ПААГ по одому белковому компоненту с $\mathrm{Rf}=0.63$ для Pisum sativum L. и с $\mathrm{Rf}=0.6$ для 
Sorghum sudanense J. (рис.1). Тетразолиевым методом для специфического проявления активности ЛЦО-подобной ГО было показано, что очищенные белки обладали гликолатоксидазной активностью. Полученные результаты свидетельствуют о том, что очищенные препараты были электрофоретически гомогенны.

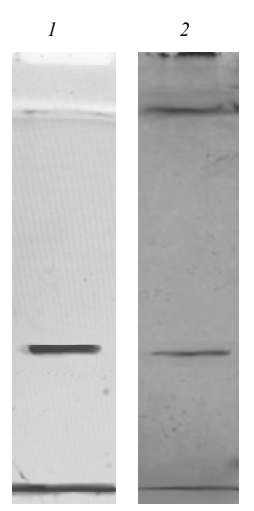

a

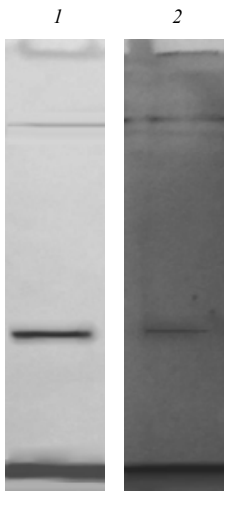

6

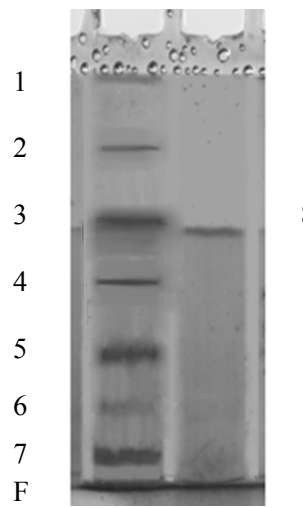

a

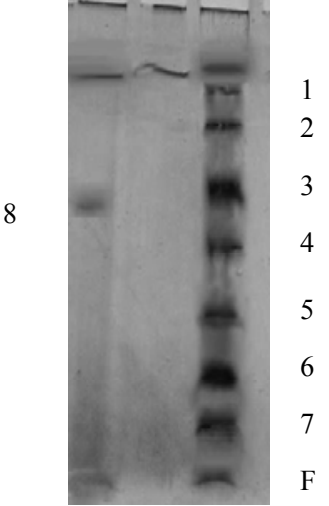

6

Рис. 1. Электофореграмма ЛЦОподобной ГО: а) из Pisum sativum L.,

б) из сорго Sorghum sudanense J. 1 - специфическое проявление тетразолиевым методом; 2 - проявление универсальным красителем на белок.

Рис. 2. Ds-Na электрофорез ЛЦОподобной ГО в $12 \%$ полиакриламидном геле в соответствии с Laemmli из а) Sorghum sudanense J., б) Pisum sativum L.; цифрами обозначены маркеры молекулярной массы: 1-b-галактозидаза (116.0),

2-БСА (66.2), 3-овальбумин (45.0), 4-ЛДГ (35.0), 5-REase Bsp198 (25.0), 6-bлактоглобулин (18.4), 7-лизоцим (14.4 (кДа), 8-ЛЦО-подобная гликолатоксидаза; F- фронт (бромфеноловый синий).

Гель-фильтрацией на колонке Сефадекс G-200 определены молекулярные массы ферментов, равные 185 и 168 кДа для гороха и сорго (рис. 3-4). Также электрофорезом в денатурирующих условиях с набором стандартных белков установлены молекулярные массы субъединиц изучаемых ферментов, составившие 45 и 42 кДа для гороха и сорго соответственно (табл. 3). Полученные данные позволяют предположить, что исследуемые ферменты представляют собой тетрамер. Согласно данным авторов гликолатоксидаза - консервативный фермент, представляющий собой тетрамер с молекулярной массой субъединиц, варьирующей от 40 до 45 кДа [17].

Таблица 3. Значения молекулярной массы и субъединичное строение ЛЦО-подобной ГО у Pisum sativum L. и Sorghum sudanense J.

\begin{tabular}{|c|c|c|c|}
\hline Объект & Молекулярная масса, кДа & $\begin{array}{c}\text { Количество } \\
\text { субъединиц }\end{array}$ & $\begin{array}{c}\text { Молекулярная масса } \\
\text { субъединиц, кДа }\end{array}$ \\
\hline Pisum sativum L. & $182.0 \pm 2.7$ & 4 & $45.0 \pm 1.9$ \\
\hline $\begin{array}{c}\text { Sorghum suda- } \\
\text { nense J. }\end{array}$ & $168.0 \pm 2.5$ & 4 & $42.0 \pm 1.3$ \\
\hline
\end{tabular}

Определённое для ЛЦО-подобной ГО гороха значение константы Михаэлиса по лактату составило 238 мкМ, для сорго - 143 мкМ, что свидетельствует о высоком сродстве данного фермента к лактату (рис. 3). Полученные значения согласуются с литературными данными по изучению ЛЦО-подобной ГО из растений риса, для ко- 
торых Км по лактату составила 470 мкМ, и арабидопсиса, для которого величина данного показателя равна - 420 мкМ [3-4].

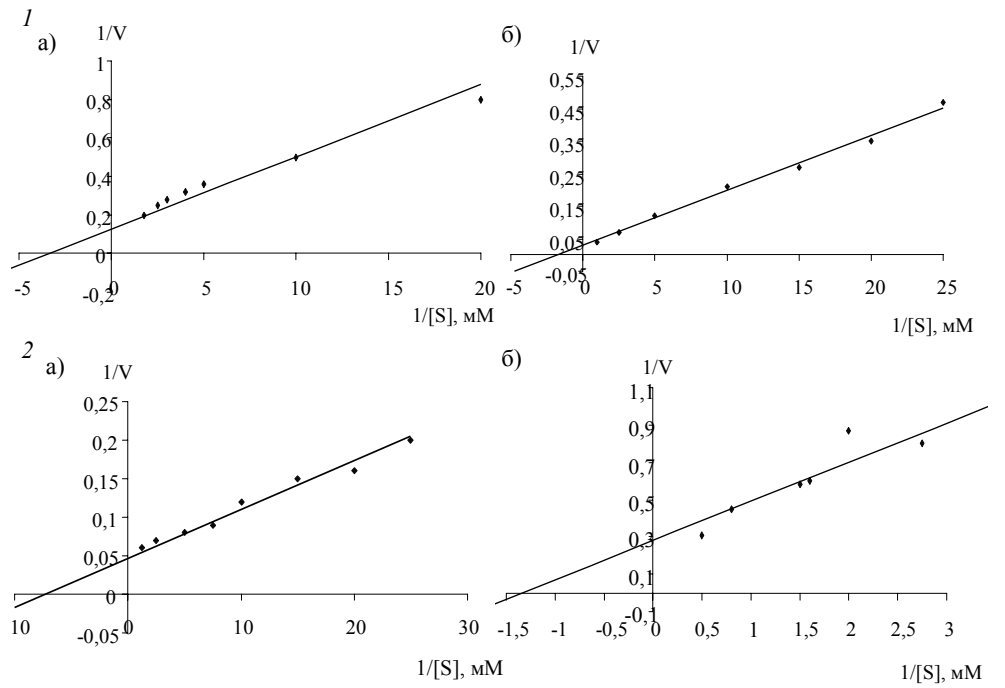

Рис. 3. Определение значений Км для ЛЦО-подобной гликолатоксидазы а) по лактату и б) по гликолату; из листьев 1 -Pisum sativum L., 2 - из Sorghum sudanense J.

a)

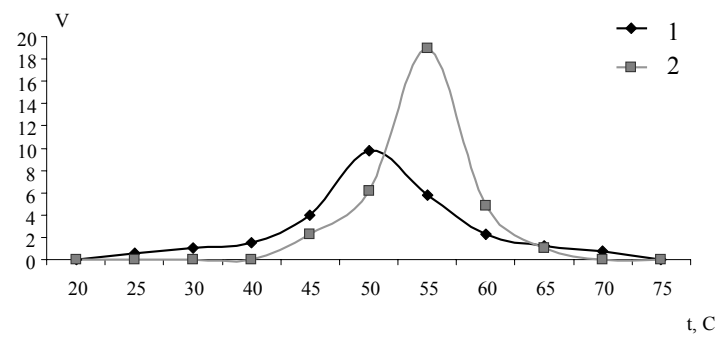

б)

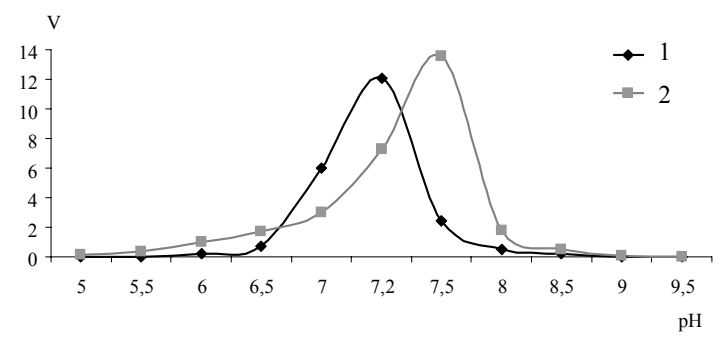

Рис. 4. Зависимость скорости реакции от а) температуры и б) $\mathrm{pH}$ среды для ЛЦО-подобной ГО из 1 - Pisum sativum L., 2 - Sorghum sudanense J. при окислении лактата

Значение константы Михаэлиса по гликолату для сорго (в листьях) составило 833 мкМ и для гороха 588 мкМ. У растений риса этот же показатель равен - 613 мкМ [4], для арабидопсиса величина Км по гликолату составила - 144 мкМ [3].

Оптимальное значение $\mathrm{pH}$ среды было определено в диапазоне буфера Tris$\mathrm{HCl}$ 5.0-9.5 и составило 7.2 и 7.5 для работы фермента ЛЦО-подобной ГО из гороха и сорго соответственно. Оптимальное значение температуры было определено в диапазоне $20-75^{\circ} \mathrm{C}$ и оказалось равным 55 и $55^{\circ} \mathrm{C}$ для энзима гороха и сорго соответственно (рис. 4). В работе Zhang et al. установлено значение оптимального рН для катализа реакции ЛЦО-подобной гликолатоксидазой риса - составило 7.8, а температурный оптимум фермента этого же представителя равен $-42^{\circ} \mathrm{C}$ [4]. 


\section{Заключение}

Таким образом, с помощью многостадийной очистки были получены в электрофоретически гомогенном состоянии препараты ЛЦО-подобной ГО из листьев гороха и сорго. Были изучены физико-химические и каталитические свойства. Установлено, что фермент представлял собой гомотетрамер. Показано, что изучаемый энзим из листьев сорго обладает более высоким сродством к субстрату лактату по сравнению с ферментом из гороха, что может способствовать повышению устойчивости растения [18]. Выявлена оптимальная для работы изучаемого фермента температура: $50^{\circ} \mathrm{C}$ для гороха и $55^{\circ} \mathrm{C}$ для сорго. Обнаружено оптимальное значение $\mathrm{pH}$ для гороха эта величина равна 7.5, и для сорго 7.2. Получение гомогенных препаратов открывает перспективы для исследования роли ЛЦО-подобной гликолатоксидазы в адаптивных реакциях клеточного метаболизма растений.

\section{Список литературы}

1. Frigerio, N. A., Harhury, H. A. // J. Biol. Chem. 1958. Vol. 231. Issue 1. pp. 135-157.

2. Hackenberg C., Kern R., Huge J., Lucas J.S. et al. // The Plant Cell. 2011. Vol. 23. pp. 29782990.

3. Engqvist M.K.M., Schmitz J., Gertzmann A., Florian A. et al. // Plant Physiol. 2015. Vol. 169. pp. 1042-1061.

4. Zhang Z., Li X., Cui L., Meng S. et al. // BMC Plant. Biol. 2017. Vol. 17. Issue 1. pp. 110.

5. Zelitch I, Schultes N.P., Peterson R.B., Brown P. et al. // Plant Physiol. 2009. Vol. 149. Issue 1. pp. 195-204.

6. Lindqvist Y., Branden L., Mathews FS, Lederer F.// J Biol Chem. 1991. Vol. 266. Issue 5. pp. 3198-3207.

7. Селеменев В.Ф., Рудаков О.Б., Славинская Г.В., Дроздова Н.В. Пигменты пищевых производств (меланоиды). М. ДеЛи ПРИНТ. 2000. 246 с.

8. Jain V., Singla N.K., Jain S., Gupta K. // Physiol Mol Biol Plants. 2010. Vol. 16. Issue 3. pp. 241-247.

9. Setsuko K., Takahiro M., Hiroshi Y. // PLos One. 2013. Vol. 8. Issue 6. e65301
10.Shevchenko A., Wilm M., Vorm O. // Anal. Chem. 1996. Vol. 68. Issue 5. pp. 850858.

11.Davis B.J., Ornstein L. // Ann. NY Acad. Sci. 1964. V. 121. pp. 404-427.

12.Карпов С.И., Roessner F., Селеменев В.Ф., Гульбин С.С. и др. // Сорбционные и хроматографические прочессы. 2013. Т. 13. № 2. C. 125-140.

13.Eprintsev A.T., Fedorin D.N., Sazonova O.V., Igamberdiev A.U. // Plant Phisiol Biochem. 2018. Vol. 129. pp. 305-309.

14.Eprintsev A.T., Fedorin D.N., Dobychina M.A., Igamberdiev A.U. // Plant Science. 2018. Vol. 272. pp. 157-163.

15.Епринцев А.Т., Гатауллина М.О. // ПБМ. 2018. Т. 54. № 3. С. 299-303.

16.Епринцев А.Т., Ларченков В.М., Комарова Н.Р., Ковалёва Е.В. и др. // ПБМ. 2018. T. 54. № 4. C. 357-361.

17.Nishimura M., Akhmedov Y. D., Strzalka K., Akazawa T. // Arch. Biochem. Biophys. 1983. Vol. 222, pp. 397-402.

18.Епринцев А.Т., Комарова Н.Р., Фалалеева М.И., Ларченков В.М. // Известия АН. Сер. биол. 2018. № 5. С. 469-475.

\section{References}

1. Frigerio N.A., Harhury H.A., J. Biol. Chem., 1958, Vol. 231, Issue 1, pp. 135-157.

2. Hackenberg C., Kern R., Huge J., Lucas J.S. et al., The Plant Cell., 2011, Vol. 23, pp. 29782990.

3. Engqvist M.K.M., Schmitz J., Gertzmann A., Florian A. et al., Plant Physiol., 2015, Vol. 169, pp. 1042-1061.

4. Zhang Z., Li X., Cui L., Meng S. et al., BMC Plant. Biol., 2017, Vol. 17, Issue 1, pp. 110.

Комарова и др. / Сорбционные и хроматографические процессы. 2019. Т. 19. № 1 
5. Zelitch I, Schultes N.P., Peterson R.B., ficheskie protsessy, 2013, Vol. 13, No 2, pp. Brown P. et al., Plant Physiol., 2009, Vol. 149, 125-140.

Issue 1, pp. 195-204.

6. Lindqvist Y., Branden L., Mathews FS, Lederer F., J Biol Chem., 1991, Vol. 266, Issue 5, pp. 3198-3207.

7. Selemenev V.F., Rudakov O.B., Slavinskaya G.V., Drozdova N.V. Pigmenty pishchnvyh proizvodstv (melanoidy), M., De Li PRINT, 2000, $246 \mathrm{p}$.

8. Jain V., Singla N.K., Jain S., Gupta K., Physiol Mol Biol Plants., 2010, Vol. 16, Issue 3, pp. 241-247.

9. Setsuko K., Takahiro M., Hiroshi Y., PLos One, 2013, Vol. 8, Issue 6. e65301

10. Shevchenko A., Wilm M., Vorm O., Anal. Chem., 1996, Vol. 68, Issue 5, pp. 850-858.

11. Davis B.J., Ornstein L., Ann. NY Acad. Sci., 1964, Vol. 121, pp. 404-427.

12. Karpov S.I., Roessner F., Selemenev V.F., Gul'bin S.S. et al., Sorbtsionnye i khromatogra-

Епринцев Александр Трофимович - професcop кафедры биохимии и физиологии клетки, д.б.н., Воронежский государственный университет, Воронеж

Фалалеева Марина Ивановна - доцент кафедры биохимии и физиологии клетки, к.б.н., Воронежский государственный университет, Воронеж

Комарова Надежда Романовна - аспирант кафедры биохимии и физиологии клетки, Воронежский государственный университет, Воронеж

Ковалёва Екатерина Вадимовна- магистр 2 года обучения кафедры биохимии и физиологии клетки, Воронежский государственный университет, Воронеж

13. Eprintsev A.T., Fedorin D.N., Sazonova O.V., Igamberdiev A.U., Plant Phisiol Biochem., 2018, Vol. 129, pp. 305-309.

14. Eprintsev A.T., Fedorin D.N., Dobychina M.A., Igamberdiev A.U., Plant Science, 2018, Vol. 272, pp. 157-163.

15. Eprincev A.T., Gataullina M.O., PBM, 2018, Vol. 54, No 3, pp. 299-303.

16. Eprincev A.T., Larchenkov V.M., Komarova N.R., Kovalyova E.V. et al., PBM, 2018, Vol. 54, No 4, pp. 357-361.

17. Nishimura M., Akhmedov Y. D., Strzalka K., Akazawa T., Arch. Biochem. Biophys., 1983, Vol. 222, pp. 397-402.

18. Eprincev A.T., Komarova N.R., Falaleeva M.I., Larchenkov V.M., Izvestiya AN. Ser. biol., 2018, No 5, pp. 469-475.

Eprintsev Alexander Trofimovich - head of the department of BPC (Federal State Budget Educational Institution of Higher Education Voronezh State University) bc366@,bio.vsu.ru

Falaleeva Marina Ivanovna - lecturer of the department of BPC, Voronezh State University, Voronezh falaleeva-m-i@yandex.ru

Komarova Nadezhda R. - the postgraduate student, department of BPC, Voronezh State University, Voronezh, e-mail: nad1989@mail.ru

Kovaleva Ekaterina Vadimovna -Master 2 years of training at the Department of Biochemistry and Cell Physiology, Voronezh State University, Voronezh bc366@,bio.vsu.ru

Mitkevich Alexandra Vladislavovna -Master 2 years of training at the Department of Biochemistry and Cell Physiology, Voronezh State University, Voronezh bc366@bio.vsu.ru 